\title{
Wood density as a proxy for vulnerability to cavitation: Size matters
}

\author{
Sabine Rosner ${ }^{1}$ \\ ${ }^{1}$ BOKU Vienna, Institute of Botany, Gregor Mendel Str. 33, A-1180 Vienna, Austria
}

Corresponding author: Sabine Rosner, sabine.rosner@boku.ac.at

Date of submission: 26/10/2016

Date of publication: $14 / 01 / 2017$

\begin{abstract}
In this study, vulnerability to cavitation, $P_{50}$ (i.e. the water potential causing $50 \%$ loss of hydraulic conductivity), of Norway spruce trunkwood at different cambial age was related to wood density. Wood density was calculated from mass in the oven dry state related either to volume at the oven-dry state (dry wood density) or to volume at full saturation (basic wood density). Dry wood density and basic wood density were strongly linearly related $\left(r^{2}=0.99\right)$; there was however a shift from the $1: 1$ reference line with increasing dry wood density. Dry wood density as well as basic wood density had similar high predictive qualities for $P_{50}\left(r^{2}=0.85\right)$. The quadratic regression lines took however a quite different course below -4 MPa because volume shrinkage increased with increasing dry wood density. For Norway spruce sapwood with high dry wood density, mixing up different wood density traits would thus result in a predicted overestimation or underestimation of vulnerability to cavitation. Gravimetrically wood density measurements at different moisture contents (starting at full saturation) are easily to achieve on standard size specimens and the conversion curves obtained will be of high value for future ecological studies on other species and across species.
\end{abstract}

\section{Introduction}

Wood density is regarded as a functional trait in ecophysiological research and has been used so far in many metaanalyses in order to learn more about the different strategies of tree species to survive drought (e.g. Chave et al., 2009; Schuldt et al., 2013; Anderegg et al., 2016; Gleason et al., 2016; Jupa et al., 2016). In conifers, strong relationships between vulnerability to cavitation and wood density were found across species (Hacke et al., 2001; Hacke and Jansen, 2009; Lachenbruch and McCulloh, 2014) and within a given species (Domec et al., 2009; Rosner, 2013, Rosner et al., 2014). Several studies report however either weak or no such within-species- (Martínez-Vilalta et al., 2009; Corcuera et al., 2011; Lamy et al., 2012) or interspecies correlations (Gleason et al., 2016).

Hacke et al. (2001) hypothesized that greater resistance to cavitation requires a safer design for resisting implosion since cell walls have to withstand higher tensile strain before the water column breaks. Based on the assumption that mechanical strength and stiffness increase with increasing wood density, tensile stress in a water filled conduit at a given water potential should increase with decreasing squared double wall/lumen ratio (Hacke et al., 2001; Pittermann et al., 2006; Domec et al., 2009). Wood density is affected by anatomical and chemical traits that determine how much mass can be found in a given volume. These relationships are much simpler in conifers than in angiosperms. Conifer wood consists mainly of tracheids and has less than $10 \%$ parenchyma tissue (Morris et al., 2016) and its wood density is strongly related to latewood percentage (Domec et al., 2009). Angiosperm wood can have - even within a narrow density range - variable amounts of fibre wall-, fiber lumen- and parenchyma fractions (Ziemińska et al., 2015). Moreover, in some species, wood density is mainly driven by the density of tissues outside the vessels rather than by the vessel lumen fraction (Ziemińska et al., 2013). The characteristics of the vessels (diameter, wall thickness) should however determine hydraulic functioning (Awad et al., 2010). Density has no direct effect on hydraulic functioning; empirical relationships exist because some of these traits that affect density also affect hydraulics (Lachenbruch and McCulloh, 2014). Thus, the statistical relationship between vulnerability to cavitation and wood density is no direct relationship. In fact, in conifers, vulnerability to cavitation is related to the characteristics of the membranes of bordered pits (Domec and Gartner, 2002b, Delzon et al., 2010; Pittermann et al., 2010; Jansen et al., 2012; Bouche et al., 2014). Seal capillary-seeding, i.e. when the torus is not tightly sealed against the pit border, either due to weak aspiration or poor air tightness of the torus/pit aperture interface, is regarded as the 
most likely mode of air-seeding in bordered pits of conifers (Delzon et al., 2010). Earlywood tracheids with thicker cell walls may have bordered pits that are less prone to seal capillary-seeding. In that regard, "It is entirely appropriate to take advantage of these indirect correlations as long as the proxy is presented as what it is, and the correlation is expected to be valid over the conditions used." (Lachenbruch and McCulloh, 2014).

In ecological studies, the functional trait "wood density" is referred to "basic wood density", that is the wood mass in the oven dry state divided by the volume in the green state. Basic wood density datasets for many species have been made available (e.g. Zanne et al., 2009). On the other hand, there is an increasing trend to analyze within-ring differences of wood density by means of x-ray transmission and relate that to hydraulic performance of a given species (e.g. Dalla-Salda et al., 2014; Martinez-Meier et al., 2015; Wilkinson et al., 2015). Wood density assessed by $\mathrm{X}$-ray transmission is based on the wood mass in the oven dry state divided by the volume in the oven dry state (or at equilibrium moisture content below fiber saturation) and is thus a different trait than "basic wood density". In wood technology research, density where mass and dimensions are measured either in the oven dry state or at equilibrium moisture content (in general 12\%) is traditionally termed "(dry) wood density". The incompatibility of "basic wood density" and "dry wood density" is due to dimensional changes during moisture loss that become more relevant with increasing density of a given wood specimen (Simpson, 1993) because "moisture-induced dimensional change increases as wood density increases." (Forest Products Laboratory, 2010). Moreover, dimensional changes in detached sapwood can be observed above fiber saturation (i.e. about $30 \%$ moisture content), thus when there is still free water in the conduit lumen (Rosner et al., 2009).

Aim of this study is to emphasize the importance of a clear terminology when "wood density" is used as a functional trait or as a proxy for hydraulic vulnerability and to create awareness for its high variability within a conifer species. $P_{50}$ (i.e. the water potential causing $50 \%$ loss of hydraulic conductivity) of Norway spruce (Picea abies [L.] Karsten) trunkwood of different cambial age from mature and young trees was related to wood density calculated either from volume at the oven dry state (dry wood density) or from volume at full saturation (basic wood density) and the results are compared.

\section{Materials and Methods}

\section{Plant material}

The dataset for $P_{50}$, dry wood density and basic wood density of Norway spruce (Picea abies (L.) Karst.) comprised existing datasets as well as new measurements.

\begin{tabular}{|l|l|l|l|c|c|c|c|}
\hline Country & Site & Lat. & Long. & $\begin{array}{c}\text { Tree age } \\
{[\mathrm{a}]}\end{array}$ & $\begin{array}{c}\text { Trees } \\
\mathrm{n}\end{array}$ & $\begin{array}{c}\text { Tree height } \\
{[\mathrm{m}]}\end{array}$ & $\begin{array}{c}\text { Whorls from top } \\
\mathrm{n}\end{array}$ \\
\hline Austria & Kalwang & $47^{\circ} 25^{\prime} \mathrm{N}$ & $14^{\circ} 45^{\prime} \mathrm{E}$ & 4 & 10 & $0.57 \pm 0.06$ & 3 \\
\hline Germany & Laufen & $47^{\circ} 56^{\prime} \mathrm{N}$ & $12^{\circ} 56^{\prime} \mathrm{E}$ & 5 & 40 & $0.60 \pm 0.03$ & 3 \\
\hline Sweden & Tönnersjöheden & $56^{\circ} 67^{\prime} \mathrm{N}$ & $13^{\circ} 07^{\prime} \mathrm{E}$ & 24 & 30 & $10.82 \pm 0.27$ & $17-19$ \\
\hline Sweden & Vissefjärda & $56^{\circ} 54^{\prime} \mathrm{N}$ & $15^{\circ} 53^{\prime} \mathrm{E}$ & 24 & 30 & $9.26 \pm 0.29$ & $17-19$ \\
\hline Norway & Sande & $59^{\circ} 35^{\prime} \mathrm{N}$ & $10^{\circ} 12^{\prime} \mathrm{E}$ & 40 & 12 & $21.18 \pm 0.41$ & 10 \\
\hline Norway & Hoxmark & $59^{\circ} 40^{\prime} \mathrm{N}$ & $10^{\circ} 45^{\prime} \mathrm{E}$ & 50 & 12 & $22.60 \pm 0.38$ & 10 \\
\hline
\end{tabular}

Table 1: Plant material

Overview of the sample set and the absolute and relative height (internodes from the top) of the trees where the air seeding pressure $\left(\mathrm{P}_{50}\right)$, dry wood density and basic wood density were measured.

Information on the origin of the plant material, age of trees and sampling location within the trees can be found in Table 1 . The parameter set is described in detail in Table 2. 
$P_{50}$ (air pressure that results in $50 \%$ conductivity loss) was assessed by the air injection method. The air injection technique enables the construction of a whole vulnerability curve on a given sample within a few hours (Cochard et al., 2013) up to one (working) day. Sapwood specimens of mature and young trunkwood had a size of $6 \mathrm{~mm}$ (radial), 6 $\mathrm{mm}$ (tangential) and $110 \mathrm{~mm}$ (longitudinal). Specimen from small trees had a length of $110 \mathrm{~mm}$ and a variable diameter that was smaller than $7 \mathrm{~mm}$. Specimen for hydraulic testing comprised 1-3 complete annual rings, those were rings 1-3 in specimens from Austria and Germany, rings 8-10 in specimens from Norway and rings 17-19 in specimens from Sweden.

For hydraulic testing, specimens from small trees were debarked (more details in Rosner et al., 2007); whereas small wood beams were produced form the trunkwood samples of older trees with a chisel and by planing on a sliding microtome (Rosner et al., 2008). Specimens were kept wet during all preparation steps. Wood specimens were soaked in distilled water under partial vacuum at $4^{\circ} \mathrm{C}$ for at least $48 \mathrm{~h}$ to refill embolized tracheids. Hydraulic flow measurements were carried out under a pressure head of $8.0 \mathrm{kPa}$ (specimen from small trees) or $5.4 \mathrm{kPa}$ (wood beams) with distilled, filtered $(0.22 \mu \mathrm{m})$, and degassed water containing 0.005 vol. \% Micropur (Katadyn Products Inc., Wallisellen, Switzerland). After the first conductivity measurement at full saturation, air overpressure was applied by means of a double-ended pressure chamber (PMS Instruments Co., Corvallis, Oregon). After a relaxation period in distilled water of 30 minutes, hydraulic conductivity was measured again. The first pressure application was $1.0 \mathrm{MPa}$, thereafter the pressure was subsequently increased in steps of 0.5 - 1.0 MPa until more than $90 \%$ loss of conductivity was reached. $P_{50}$ values for each sapwood beam were calculated as described in Pammenter and Vander Willigen (1998). In specimen from Norway, conductivity measurements were performed only until $70 \%$ loss of hydraulic conductivity, since that proved sufficient to calculate reliable $P_{50}$ values for each tree segment (Rosner et al., 2014).

\begin{tabular}{|c|c|c|c|c|c|c|c|}
\hline Country & Site & $\begin{array}{l}P_{50} \\
\text { Data source }\end{array}$ & n & $\begin{array}{l}\text { DWD } \\
\text { Data source }\end{array}$ & n & $\begin{array}{l}\text { BWD } \\
\text { Data source } \\
\end{array}$ & n \\
\hline Austria & Kalwang & New & 6 & New & 10 & New & 10 \\
\hline Germany & Laufen & Rosner et al. 2007 & 40 & Rosner et al. 2007 & 40 & & 0 \\
\hline Sweden & Tönnersjöheden & Rosner et al. 2008 & 30 & Rosner et al. 2014 & 30 & Rosner et al. 2008 & 30 \\
\hline Sweden & Vissefjärda & Rosner et al. 2008 & 30 & Rosner et al. 2014 & 30 & Rosner et al. 2008 & 30 \\
\hline Norway & Sande & Rosner et al. 2014 & 12 & Rosner et al. 2014 & 12 & New & 12 \\
\hline Norway & Hoxmark & Rosner et al. 2014 & 12 & Rosner et al. 2014 & 12 & New & 12 \\
\hline Sum & & & 130 & & 134 & & 94 \\
\hline
\end{tabular}

\section{Table 2: Data sources}

Overview of the data sources comprising air seeding pressure $\left(\mathrm{P}_{50}\right)$, dry wood density (DWD) and basic wood density (BWD). For all trees, dry wood density was assessed $(n=134) . \mathrm{P}_{50}$ was calculated only for six trees harvested in Kalwang; the number of available $\mathrm{P}_{50}$ values was thus 130 . For trees originating from Germany no basic wood density dataset existed; basic wood density was calculated with an empirical equation (Equ. 1, in the results part) from the relationship between dry- and basic wood density of 94 specimens.

\section{Basis wood density and dry wood density}

Basic wood density was defined as the mass (weight) in the oven dry state divided by the volume in the fully saturated green state $\left[\mathrm{kg} \mathrm{m}^{-3}\right]$. Dimensions for calculating the volume at the fully saturated green (never dried) state were measured with a caliper (resolution of $0.1 \mathrm{~mm}$ ) after saturation at partial vacuum under water (Hietz et al., 2008). The volume was determined before the hydraulic flow measurements. Dry wood density was defined as the volume in the oven dry state divided by the mass in the oven dry state $\left[\mathrm{kg} \mathrm{m}^{-3}\right]$.

Specific gravity is often mixed up with density. Specific gravity of wood can be calculated by dividing dry wood density by the density of water at $4.4^{\circ} \mathrm{C}\left(1000 \mathrm{~kg} \mathrm{~m}^{-3}\right)$. From the standpoint of physics, specific gravity is defined as the density of wood where mass and volume are determined in the same (oven dry) state relative to the density of water (Williamson and Wiemann, 2010). After flow measurements, specimens were dried for 48 hours at $103^{\circ} \mathrm{C}$ in order to determine weight and volume at the oven dry state. Lower temperatures can result in remainders of bound water in the cell walls (Williamson and Wiemann, 2010). After drying, specimens were immediately transferred from 
the oven into an exsiccator containing dried silica gel. As soon as the wood specimens had reached room temperature, they were weighed (one by one, the rest remained in the exsiccator) and their dimensions were determined by means of a caliper. Volume shrinkage was calculated as the volume loss from the fully saturated state to the oven dry state related to the volume in the fully saturated state (in \%).

\section{Results}

Stem wood from small trees had much lower $P_{50}$ values $(-4.88 \pm 0.62 \mathrm{MPa})$ than sapwood from the crown $(-2.55 \pm$ $0.45 \mathrm{MPa})$ or from the lower trunk $(-2.44 \pm 0.21 \mathrm{MPa})$. Dry wood density and basic wood density were strongly linearly related (Fig. 1). With increasing wood density there was however a shift from the 1:1 reference line. The equation for calculating basic wood density from dry wood density of Norway spruce sapwood across cambial age was:

$$
\text { Basic wood density }=37.39+0.815 * \text { dry wood density } \quad\left[\mathrm{kg} \mathrm{m}^{-3}\right] \quad \text { [Equation 1] }
$$

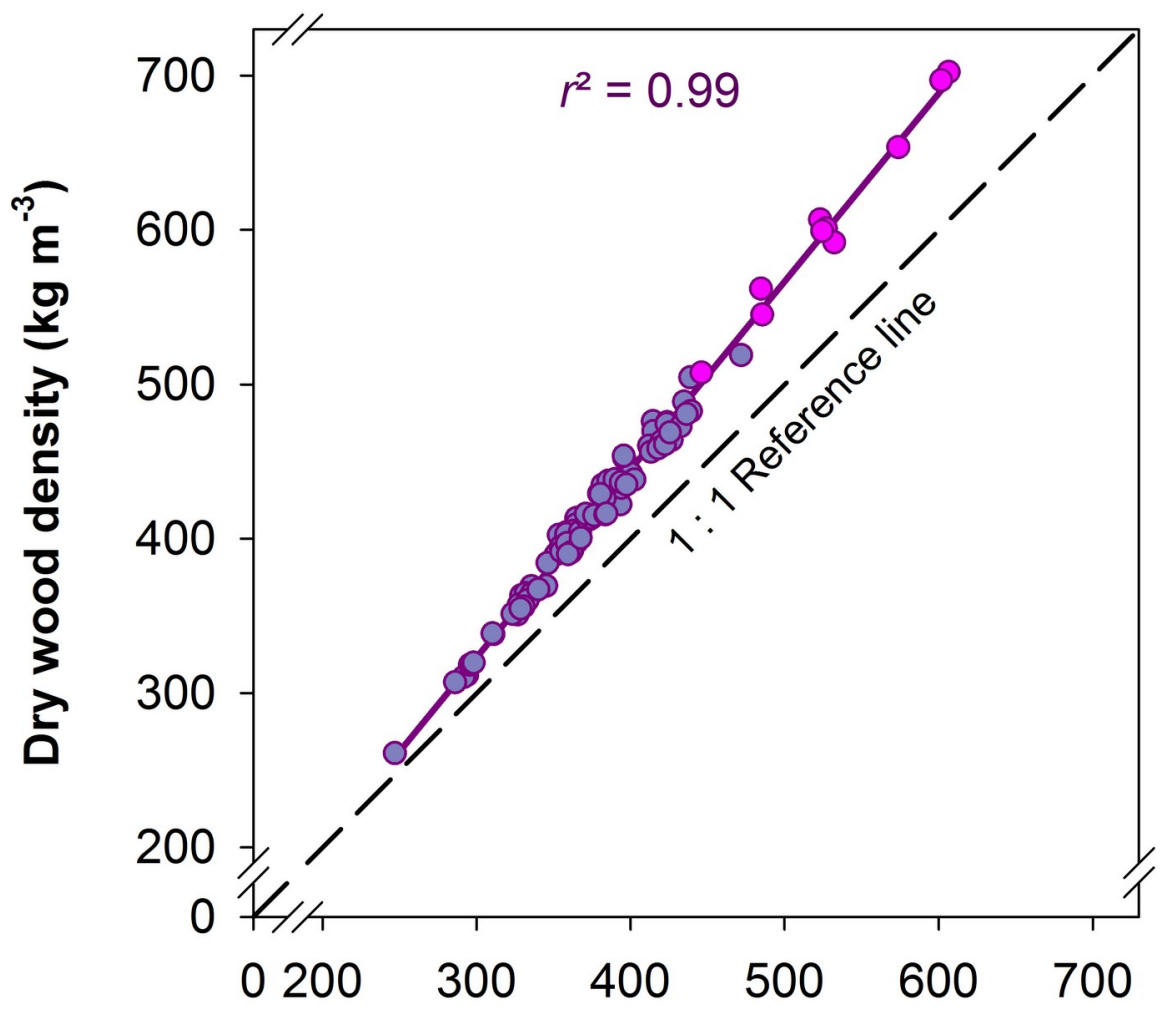

\section{Basic wood density $\left(\mathrm{kg} \mathrm{m}^{-3}\right)$}

Figure 1: Relationship between basic wood density and dry wood density in Norway spruce sapwood.

Lilac symbols present sapwood specimens without pith tissue (wood beams), pink symbols specimens with pith tissue (stem specimen of young trees). The linear regression is significant at the $0.01 \%$ level $(\mathrm{P}<0.0001, \mathrm{n}=94)$. The equation is as follows: Dry wood density $=-42.16+1.218 *$ basic wood density $\left[\mathrm{kg} \mathrm{m}^{-3}\right]$.

The relationship between $P_{50}$ and dry wood density as well as basic wood density is shown in Fig. 2. Basic wood density data for young trees from Germany were calculated from dry wood density data with Equation 1 . Due to the shift from the 1:1 reference that increased with increasing wood density (Fig. 1), the quadratic regression lines took a quite different course below -4 MPa. For sapwood with high wood density, mixing up different wood density traits would result in an overestimation (basic wood density used in an empirical model for $P_{50}$ and dry wood density) or underestimation (dry wood density used in an empirical model for $P_{50}$ and basic wood density) of vulnerability to cavitation. Overestimation is meant as the prediction of higher vulnerability to cavitation, thus a lower hydraulic safety of up to $2 \mathrm{MPa}$ (Fig. 3), underestimation the prediction of a much higher hydraulic safety. The relationship between dry wood density and volume shrinkage of Norway spruce sapwood is presented in Fig. 4. Volume shrinkage and thus the shift from the 1:1 relationship between dry wood density and basic wood density (Fig. 1) increased with increasing dry wood density. 


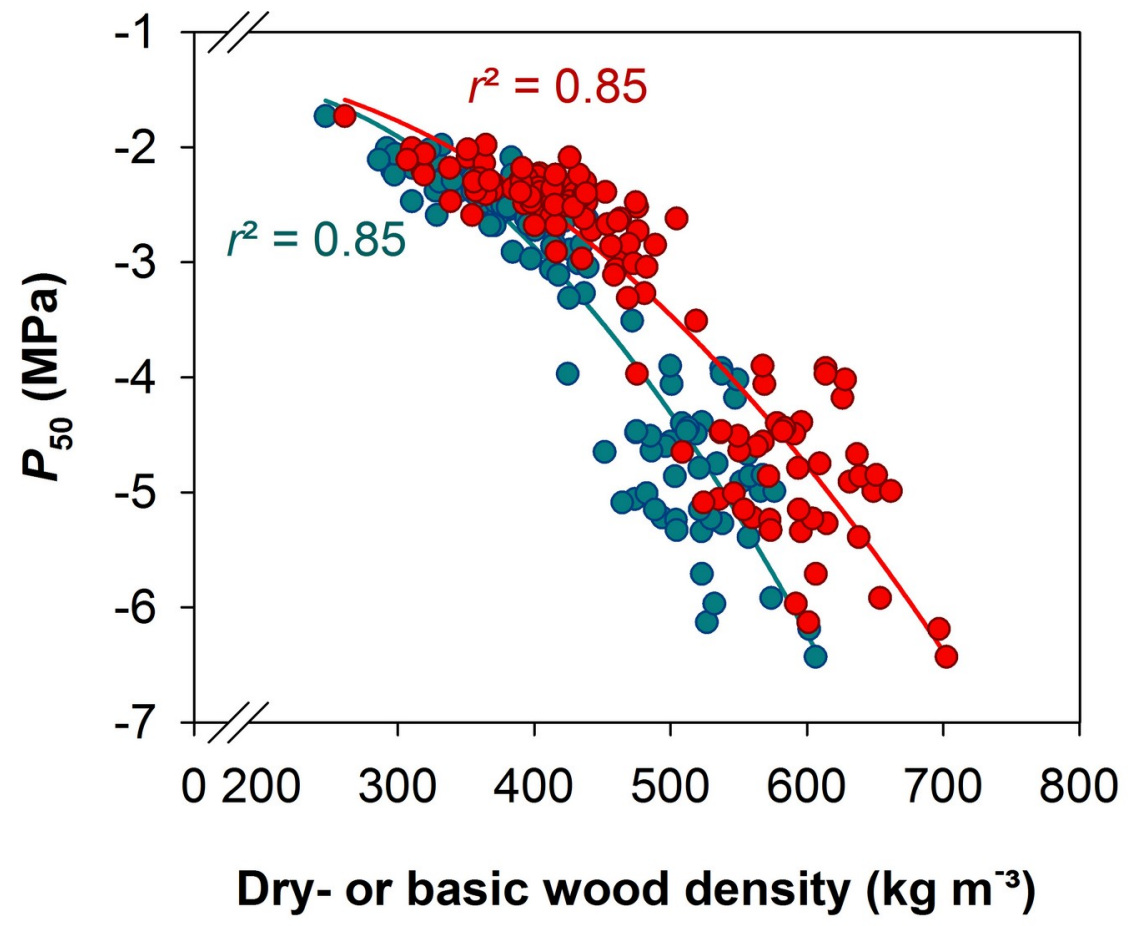

Figure 2: Relationship between wood density traits and vulnerability to cavitation.

$\mathrm{P}_{50}$ is plotted against dry wood density (red symbols) and basic wood density (blue symbols). Quadratic regressions are significant at the $0.01 \%$ level $(\mathrm{P}<0.0001, \mathrm{n}=130)$.

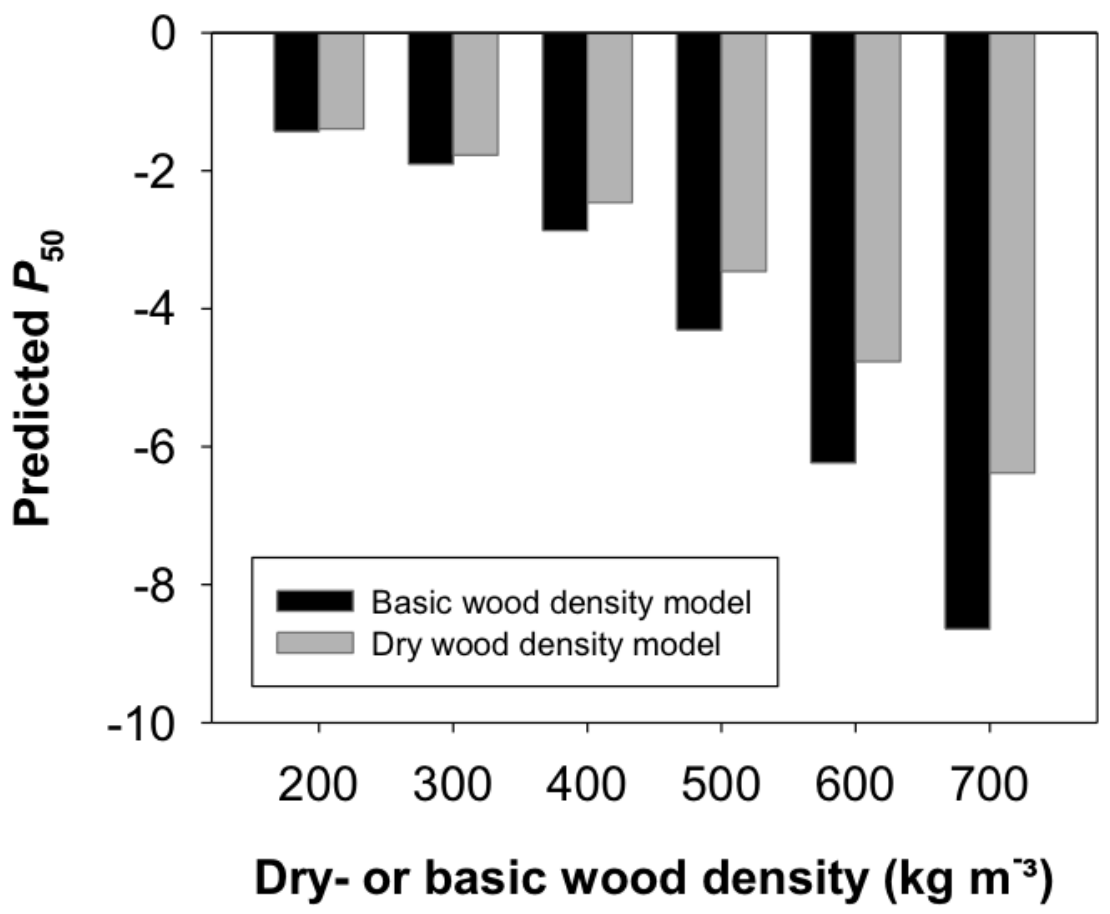

Figure 3: Hydraulic vulnerability predicted by different empirical models.

$\mathrm{P}_{50}$ predicted for wood density data using either empirical models for basic wood density or dry wood density. Regression lines for the models are given in Fig.2. 


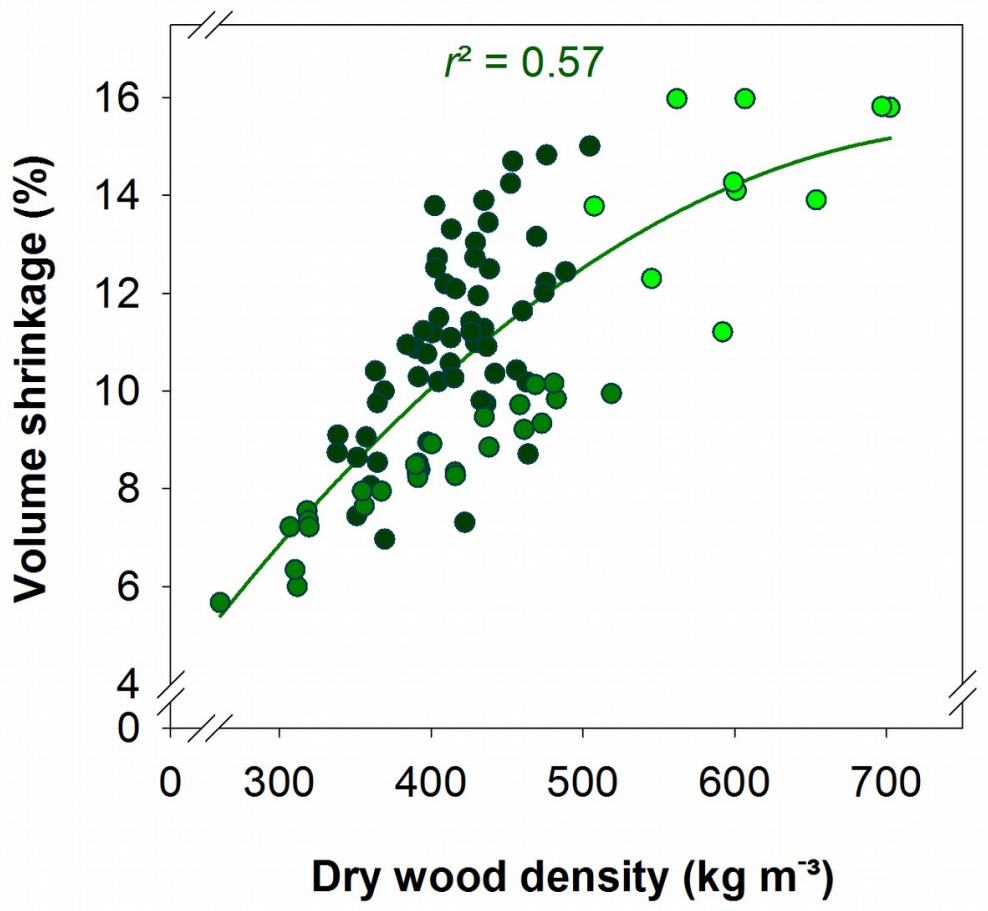

Figure 4: Volume shrinkage related to dry wood density.

The quadratic regression is significant at the $0.01 \%$ level $(P<0.0001, n=94)$. Light green dots represent young trees $($ Austria), green dots young trunkwood (Norway) and dark green dots mature trunkwood (Sweden).

\section{Discussion}

Basic wood density was strongly linearly related to dry wood density in Norway spruce sapwood (Fig. 1); shifts from a 1:1 relationship could be explained by differences in volume shrinkage (Fig. 4). Volume shrinkage of Norway spruce sapwood presented in this study (Fig. 4) corresponded to that reviewed in literature (Kärkkäinen and Marcus, 1985). Wood structure is variable within a tree and between different trees and so is volumetric shrinkage. A general concept is that volume shrinkage below fiber saturation increases with dry wood density (Simpson, 1993; Forest Products Laboratory, 2010). Fiber saturation is defined as a state during a dehydration cycle when cell lumina contain no longer free water but when cell walls are fully saturated with liquid (Stamm, 1971; Skaar, 1988; Berry and Roderick, 2005). When conduits reach moisture contents below fiber saturation, the cell wall shrinkage process is initiated. Radial and tangential wall shrinkage, summarized as transverse shrinkage, account for most of the volumetric shrinkage, whereas shrinkage in the longitudinal direction is often much below 1\% (Kärkkäinen and Marcus, 1985). Transverse cell wall shrinkage decreases with decreasing dry wood density (Stamm, 1971; Skaar 1988; Chafe and Ilic, 1992; Pang and Herritsch, 2005). Cellulose microfibrils of the tracheid walls are embedded in an amorphous matrix. This matrix tends to contract isotropically when it loses water. The microfibrils deform the matrix when resisting this contraction (Barber and Meylan, 1964). In this study, highest wood density values were found for stem wood of very young Norway spruce trees. Strictly spoken, wood density of these specimens is "stem density without bark" because such specimens (also branches) include pith tissue. However, the linear relationship between dry wood density and basic wood density was not influenced by the presence of pith tissue. The regression line drawn across cambial age had exactly the same course as those for wood of young trees and older trees (Fig. 1). Care was taken that only specimens with a small amount of pith were used for the study (Rosner et al., 2014). In addition, the presence of the pith in specimens from small trees led to no exponential increase in volumetric shrinkage (Fig. 4). Rather the opposite was the case, as indicated by the depletion of the quadratic regression curve when volumetric shrinkage was plotted against dry wood density. For young branch wood or trunkwood of species with a very high amount of pith tissue results might differ.

$P_{50}$ showed a quite wide range in Norway spruce sapwood specimens. This is not surprising, because sapwood with extreme differences in wood structure originating from small trees (Fig. 5a) and the mature trunk (Fig. 5b) were investigated. When conifer branches (e.g. Dalla-Salda et al., 2009; Corcuera et al., 2011; Lamy et al., 2014), young stems (e.g. Rosner et al., 2007; Sáenz-Romero et al., 2013) or mature trunkwood of similar cambial age (e.g. Rosner et al., 2008; Dalla-Salda et al., 2009) is tested much narrower $P_{50}$ ranges are observed. Within-species variation in $P_{50}$ of sapwood of a given organ at similar cambial age can be a result of genetic determination and site conditions (Rosner et al., 2007; Rosner et al., 2008; Corcuera et al., 2011; Sáenz-Romero et al., 2013) or driven by sudden 
drought events (Rosner et al., 2014). Differences in $P_{50}$ of a given organ observed so far made up however not much more than 1.5 MPa in conifers (e.g. Dalla-Salda et al., 2009; Lamy et al., 2011; Corcuera et al., 2011; Rosner et al., 2016) and in angiosperms (e.g. Awad et al., 2010). Some conifer species, especially pines, exhibit a much lower genotypic variability and phenotypic plasticity (Sáenz-Romero et al., 2013; Lamy et al., 2014) than Norway spruce (Rosner et al., 2007; 2008). As mentioned above, the sample set comprised trunkwood from young small trees with a very high hydraulic safety and sapwood from the mature trunk that had much lower hydraulic safety. High intraspecific variability in $P_{50}$ has been reported for other conifer species too; Domec et al. (2009) found $P_{50}$ values in Douglas fir ranging in roots from -1.4 MPa to -1.0MPa, in the main trunk from -4.1 to -3.2 MPa and in branches from -6.1 to -5.9 MPa. In Ponderosa pine, $P_{50}$ ranged from -1.5 to $-0.7 \mathrm{MPa}$ in roots, from -4.1 to $-3.2 \mathrm{MPa}$ in the main trunk and from -4.7 to $-4.5 \mathrm{MPa}$ in branches. Recently, Bouche et al. (2016) found however low inter-organ variability in $P_{50}$ in four different Pinaceae species, including Douglas fir. Stem wood of young small spruce trees (seedling size) investigated in the present study had a mean $P_{50}$ of $-4.88 \mathrm{MPa}$. This is slightly lower than $P_{50}$ of $-4.38 \mathrm{MPa}$ found by Mayr et al. (2003) for leader shoots of older Norway spruce trees. The high hydraulic safety demand in the sapwood of small young trees might be explained by the shallow root system of seedlings that implies less access to ground water (Rosner, 2013). Accordingly, in Douglas fir seedlings (2nd internode from top) $P_{50}$ can be much lower (-5.6 $\mathrm{MPa}$ ) than at the base of the trunk of old trees (-3.3 MPa) of the same species (Domec and Gartner, 2002a).
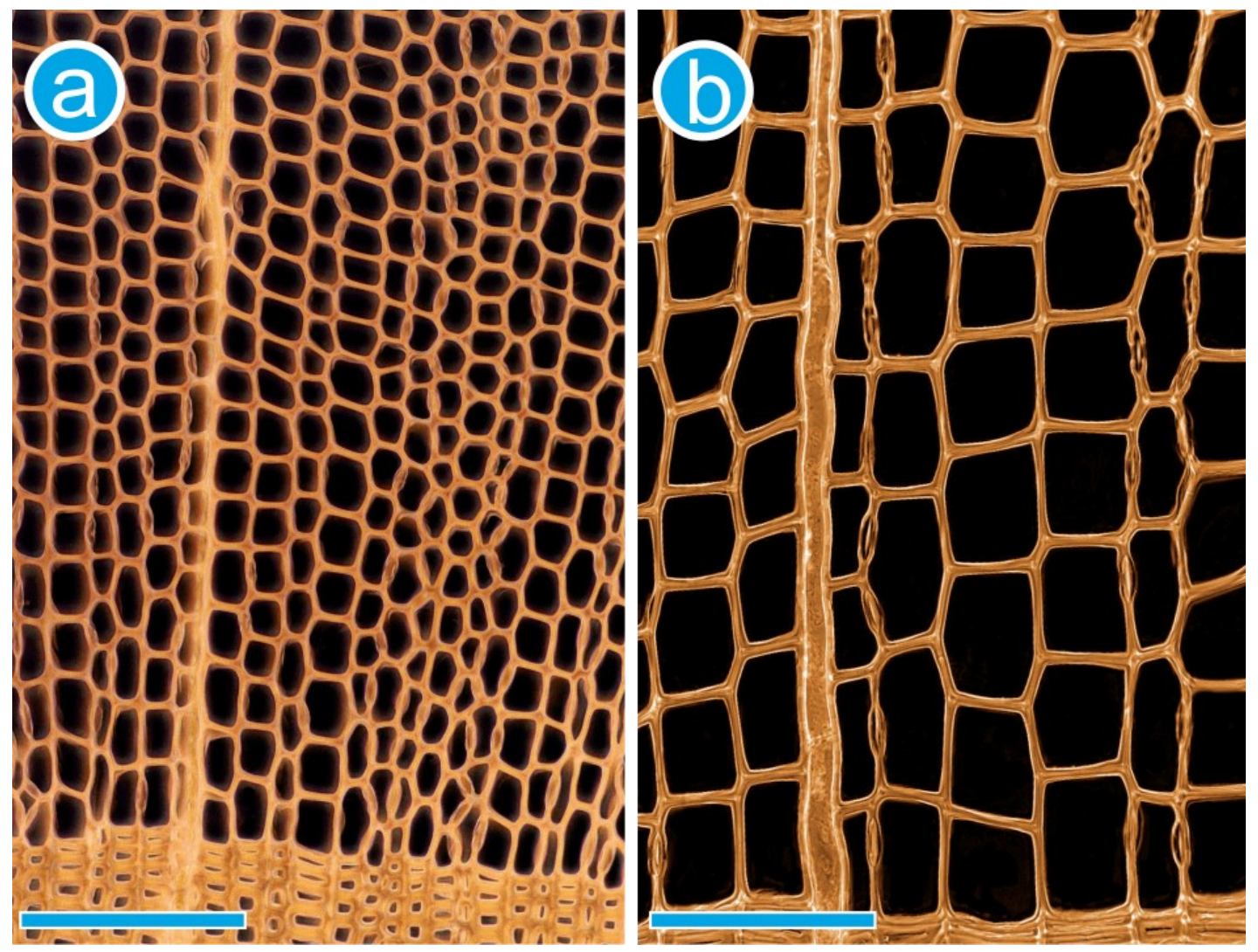

Figure 5: Transverse section of Norway spruce trunkwood at different cambial age from a young and an older tree.

Anatomy of Norway spruce earlywood and latewood formed in the previous growing season from the trunk of a young small tree from Germany (a) and of a mature tree from southern Sweden (b). $\mathrm{P}_{50}$ of the sample in (a) was -5.27 MPa and in (b) -2.20 MPa. In (a) earlywood is from annual ring three from the third whorl from the top, in (b) from annual ring 19 in breast height. Sections with a thickness of $20 \mu \mathrm{m}$ were stained with methylene blue; colors were inverted in the digitized images. Reference bars indicate $100 \mu \mathrm{m}$. Information on study sites and sampling can be found in Tables 1 and 2.

Whereas strong relationships were found between $P_{50}$ and basic wood density within conifer species across cambial age (Domec et al., 2009; Rosner et al., 2014) no such relationships have been reported for conifer branch wood (Martínez-Vilalta et al., 2009; Corcuera et al., 2011; Lamy et al., 2012). Branch wood contains however variable amounts of compression wood that has higher wood density but also higher hydraulic vulnerability than opposite wood (Mayr and Cochard, 2003). In branches, the mechanical demands might mask the empirical relationship between wood density and $P_{50}$ (Rosner et al., 2007; Rosner, 2013). In the dataset presented in this study, dry wood density (Rosner et al., 2014) and basic wood density were strongly related to $P_{50}$ across cambial age in Norway spruce trunkwood (Fig. 2). The regression lines shifted however from each other with increasing wood density. Mixing up different wood density parameters can thus lead to wrong prediction of drought sensitivity of a 
given species (Fig. 3). Basic wood density is oven-dry mass related to the volume in the green wood state and should be thus a more reliable ecological trait than dry wood density or density at defined equilibrium moisture content (below fiber saturation). However, determination of the volume in the green state can bear sources of errors, because dimensional changes in detached sapwood can be observed already above fiber saturation (i.e. about $30 \%$ moisture content), thus when there is still free water in the conduits (Rosner et al., 2009). In that regard, volume at the "green state" is a rather vague definition and shall be replaced by volume at the fully saturated state.

Across species, conversion formulas between wood densities at variable moisture contents are available (e.g. Forest Products Laboratory, 2010, Chapter 4, Tables 4-6a and 4-6b); the best conversion formula is however the one that is species-specific and that covers the whole wood density range of between-tree and within-tree differences. Such relationships are unavailable yet for most tropical wood species (Williamson and Wiemann, 2010). In species with high wood density, volume shrinkage of more than $20 \%$ can be expected (Forest Products Laboratory, 2010). Conversion formulas have been developed for lumber (mainly mature trunkwood) in order to calculate e.g. shipping weights and they might not take into account within-tree variability. In species where branches or very young trunks have quite high densities (compared to the main mature trunk) these formulas are not applicable. Moreover, the formulas include heartwood and sapwood and do not cover the whole moisture content range that is possible in sapwood of living trees at the fully saturated state. In principle, standardized gravimetrically wood density measurements at different moisture contents (starting at full saturation) are easily to achieve and the conversion curves obtained are of high value for ecological studies.

\section{Acknowledgements}

This work has been carried out under the framework of the COST FP1106 network STReESS and the Rise Project TOPWOOD (TOols for Phenotyping WOOD, Project ID: 645654), both financed by the EUROPEAN UNION.

\section{References}

Anderegg WR, Klein T, Bartlett M, Sack L, Pellegrini AF, Choat B, Jansen S. 2016. Meta-analysis reveals that hydraulic traits explain cross-species patterns of drought-induced tree mortality across the globe. Proceedings of the National Academy of Sciences of the United States 113: 5024-5029. doi:10.1073/pnas.1525678113

Awad H, Barigah T, Badel E, Cochard H, Herbette S. 2010. Poplar vulnerability to xylem cavitation acclimates to drier soil conditions. Physiologia Plantarum 139: 280-288. doi:10.1111/j.1399-3054.2010.01367.x

Barber NF, Meylan BA. 1964. The anisotropic shrinkage of wood. A theoretical model. Holzforschung 18:146-156. doi:10.1515/hfsg.1964.18.5.146

Berry SL, Roderick ML. 2005. Plant-water relations and the fibre saturation point. New Phytologist 168:25-38. doi:10.1111/j.1469-8137.2005.01528.x

Bouche PS, Larter M, Domec J-C, Burlett R, Gasson P, Jansen S, Delzon S. 2014. A broad survey of hydraulic and mechanical safety in the xylem of conifers. Journal of Experimental Botany 65: 4419-4431. doi:10.1093/jxb/eru218

Bouche PS, Jansen S, Cruz Sabalera J, Cochard H, Burlett R, Delzon S. 2016. Low intra-tree variability in resistance to embolism in four Pinaceae species. Annals of Forest Science 73: 681. doi:10.1007/s13595-016-0553-6

Chafe SS, Ilic J. 1992. Shrinkage and collapse in thin sections and blocks of Tasmanian mountain ash regrowth, Part I: shrinkage, specific gravity and the fibre saturation point. Wood Science and Technology 34:533-542. doi:10.1007/bf00194467

Chave J, Coomes DA, Jansen S, Lewis SL, Swenson NG, Zanne AE. 2009. Towards a worldwide wood economics spectrum. Ecology Letters 12(4): 351-366. doi:10.1111/j.1461-0248.2009.01285.x

Cochard H, Bardel E, Herbette S, Delzon S, Choat B, Jansen S. 2013. Methods for measuring plant vulnerability to cavitation: a critical review. Journal of Experimental Botany 64(15): 4779-4791. doi:10.1093/jxb/ert193

Corcuera L, Cochard H, Gil-Pelegrin E, Notivol E. 2011. Phenotypic plasticity in mesic populations of Pinus pinaster improves resistance to xylem embolism (P50) under severe drought. Trees 25:1033-1042. doi:10.1007/s00468011-0578-2

Dalla-Salda G, Fernández ME, Sergent A-S, Rozenberg P, Badel E, Martinez-Meier A. 2014. Dynamics of cavitation in a Douglas-fir tree-ring: transition-wood, the lord of the ring? Journal of Plant Hydraulics 1: e-0005. doi:10.20870/jph.2014.e005

Dalla-Salda G, Martinez-Meier A, Cochard H, Rozenberg P. 2009. Variation of wood density and hydraulic properties of Douglas-fir (Pseudotsuga menziesii (Mirb.) Franco) clones related to a heat and drought wave in France. Forest Ecology and Management 257: 182-189. doi:10.1016/j.foreco.2008.08.019 
Delzon S, Douthe C, Sala A, Cochard H. 2010. Mechanism of water-stress induced cavitation in conifers: bordered pit structure and function support the hypothesis of seal capillary-seeding. Plant Cell \& Environment 33: 2101-2111. doi:10.1111/j.1365-3040.2010.02208.x

Domec J-C, Gartner BL. 2002a. Age- and position-related changes in hydraulic versus mechanical dysfunction of xylem: inferring the design criteria for Douglas-fir wood structure. Tree Physiology 22: 91-104. doi:10.1093/treephys/22.2-3.91

Domec J-C, Gartner BL. 2002b. How do water transport and water storage differ in coniferous earlywood and latewood? Journal of Experimental Botany 53(379): 2369-2379. doi:10.1093/jxb/erf100

Domec J-C, Warren JM, Meinzer FC, Lachenbruch B. 2009. Safety for xylem failure by implosion and air-seeding within roots, trunks and branches of young and old conifer trees. IAWA Journal 30(2): 101-120. doi:10.1163/22941932-90000207

Forest Products Laboratory. 2010. Wood handbook-Wood as an engineering material. General Technical Report FPL-GTR-190. Madison, WI: U.S. Department of Agriculture, Forest Service, Forest Products Laboratory. 508 p.

Gleason SM, Westoby M, Jansen S, Choat B, Hacke UG, Pratt RB, Bhaskar R, Brodribb TJ, Bucci SJ, Cao KF, Cochard H, Delzon S, Domec J-C, Cao KF, Feild TS, Jacobsen AL, Jacobsen AL, Lens F, Maherali H, MartínezVilalta J, Mayr S, McCulloh KA, Mencuccini M, Mitchell PJ, Morris H, Nardini A, Pittermann J, Plavcová L, Schreiber SG, Sperry JS, Wright IJ, Zanne AE. 2016. Weak tradeoff between xylem safety and xylem-specific hydraulic efficiency across the world's woody plant species. New Phytologist 209: 123-136. doi:10.1111/nph.13646

Hacke UG, Sperry JS, Pockman WT, Davis SD, McCulloh KA. 2001. Trends in wood density and structure are linked to prevention of xylem implosion by negative pressure. Oecologia 126(4): 457-461. doi.org/10.1007/s004420100628

Hacke UG, Jansen S. 2009. Embolism resistance of three boreal conifer species varies with pit structure. New Phytologist 182: 675-686. doi:10.1111/j.1469-8137.2009.02783.x

Hietz, P., Rosner, S., Sorz, J., \& Mayr, S. (2008). Comparison of methods to quantify loss of hydraulic conductivity in Norway spruce. Annals of Forest Science, 65(5), 1. doi.org/10.1051/forest:2008023

Jansen S, Lamy J-B, Burlett R, Cochard H, Gasson P, Delzon S. 2012. Plasmodesmatal pores in the torus of bordered pit membranes affect cavitation resistance of conifer xylem. Plant, Cell and Environment 35(6): 1109-1120. doi:10.1111/j.1365-3040.2011.02476.x

Jupa R, Plavcová L, Gloser V, Jansen S. 2016. Linking xylem water storage with anatomical parameters in five temperate tree species. Tree Physiology 36: 756-769. doi:10.1093/treephys/tpw020

Kärkkäinen M, Marcus M. 1985. Shrinkage properties of Norway spruce wood. Silva Fennica 19(1): 67-72. doi:10.14214/sf.a15410

Lachenbruch B, McCulloh KA. 2014. Traits, properties, and performance: how woody plants combine hydraulic and mechanical functions in a cell, tissue, or whole plant. New Phytologist 204: 747-764. doi:10.1111/nph.13035

Lamy J-B, Bouffier L, Burlett R, Plomion C, Cochard H, Delzon S. 2011. Uniform selection as a primary force reducing population genetic differentiation of cavitation resistance across a species range. PLoS ONE 6: e23476. doi:10.1371/journal.pone.0023476

Lamy J-B, Delzon S, Bouche PS, Alia R, Vendramin GG, Cochard H, Plomion C. 2014. Limited genetic variability and phenotypic plasticity detected for cavitation resistance in a Mediterranean pine. New Phytologist 201: 874886. doi:10.1111/nph.12556

Lamy JB, Lagane F, Plomion C, Cochard H, Delzon S. 2012. Micro-evolutionary patterns of juvenile wood density in a pine species. Plant Ecology 213: 1781-1792. doi:10.1007/s11258-012-0133-2

Martinez-Meier A, Fernández ME, Dalla-Salda G, Gyenge J, Licata J, Rozenberg P. 2015. Ecophysiological basis of wood formation in ponderosa pine: Linking water flux patterns with wood microdensity variables. Forest Ecology and Management 346: 31-40. doi:10.1016/j.foreco.2015.02.021

Martínez-Vilalta J, Cochard H, Mencuccini M, Sterck F, Herrero A, Korhonen JF, Llorens P, Nikinmaa E, Nolè A, Poyatos R, Ripullone F, Sass-Klaassen U, Zweifel R. 2009. Hydraulic adjustment of Scots pine across Europe. New Phytologist 184: 353-364. doi:10.1111/j.1469-8137.2009.02954.x

Mayr S, Cochard H. 2003. A new method for vulnerability analysis of small xylem areas reveals that compression wood of Norway spruce has lower hydraulic safety than opposite wood. Plant, Cell and Environment 26: 13651371. doi:10.1046/j.0016-8025.2003.01060.x

Mayr S, Rothart B, Dämon B. 2003. Hydraulic efficiency and safety of leader shoots and twigs in Norway spruce growing at the alpine timberline. Journal of Experimental Botany 54: 2563-2568. doi:10.1093/jxb/erg272

Morris H, Plavcová L, Cvecko P, Fichtler E, Gillingham MAF, Martínez-Cabrera HI, McGlinn DJ, Wheeler E, Zheng J, Zieminska K, Jansen S. 2016. A global analysis of parenchyma tissue fractions in secondary xylem of seed plants. New Phytologist 209: 1553-1565. doi:10.1111/nph.13737

Pammenter NW, Vander Willigen C. 1998. A mathematical and statistical analysis of the curves illustrating vulnerability of xylem to cavitation. Tree Physiology 18: 589-593. doi:10.1093/treephys/18.8-9.589 
Pang S, Herritsch A. 2005. Physical properties of earlywood and latewood of Pinus radiata D. Don: anisotropic shrinkage, equilibrium moisture content and fibre saturation point. Holzforschung 59:654-661. doi.org/10.1515/HF.2005.105

Pittermann J, Choat B, Jansen S, Stuart SA, Lynn L, Dawson TE. 2010. The relationships between xylem safety and hydraulic efficiency in the Cupressaceae: The evolution of pit membrane form and function. Plant Physiology 153(4): 1919-1931. doi:10.1104/pp.110.158824

Pittermann J, Sperry JS, Wheeler JK, Hacke UG, Sikkema E.H. 2006. Mechanical reinforcement of tracheids compromises the hydraulic efficiency of conifer xylem. Plant, Cell and Environment 29(8): 1618-1628. doi:10.1111/j.1365-3040.2006.01539.x

Rosner S, Karlsson B, Konnerth J, Hansmann C. 2009. Shrinkage processes in standard-size Norway spruce wood specimens with different vulnerability to cavitation. Tree Physiology 29: 1419-1431. doi:10.1093/treephys/tpp077

Rosner S, Klein A, Müller U, Karlsson B. 2007. Hydraulic and mechanical properties of young Norway spruce clones related to growth and wood structure. Tree Physiology 27: 1165-1178. doi:10.1093/treephys/27.8.1165

Rosner S, Klein A, Müller U, Karlsson B. 2008. Tradeoffs between hydraulic and mechanical stress response of mature Norway spruce trunkwood. Tree Physiology 28: 1179-1188. doi:10.1093/treephys/28.8.1179

Rosner S, Světlík J, Andreassen K, Børja I, Dalsgaard L, Evans R, Karlsson B, Tollefsrud MM, Solberg S. 2014. Wood density as a screening trait for drought sensitivity in Norway spruce. Canadian Journal of Forest Research 44: 154-161. doi:10.1139/cjfr-2013-0209

Rosner S. 2013. Hydraulic and biomechanical optimization in Norway spruce trunkwood: A review. IAWA Journal $34:$ 365-390. doi:10.1163/22941932-00000031

Rosner, S., Světlík, J., Andreassen, K., Børja, I., Dalsgaard, L., Evans, R., ... \& Solberg, S. (2016). Novel hydraulic vulnerability proxies for a boreal conifer species reveal that opportunists may have lower survival prospects under extreme climatic events. Frontiers in Plant Science, 7, 831. doi.org/10.3389/fpls.2016.00831

Sáenz-Romero C, Lamy J-B, Loya-Rebollar E, Plaza-Aguilar A, Burlett R, Lobit P, Delzon S. 2013. Genetic variation of drought-induced cavitation resistance among Pinus hartwegii populations from an altitudinal gradient. Acta Physiologiae Plantarum 35: 2905-2913. doi:10.1007/s11738-013-1321-y

Schuldt B, Leuschner C, Brock N, Horna V. 2013. Changes in wood density, wood anatomy and hydraulic properties of the xylem along the root-to-shoot flow path in tropical rainforest trees. Tree Physiology 33: 161-174. doi:10.1093/treephys/tps122

Simpson WT. 1993. Specific Gravity, Moisture Content, and Density Relationship for Wood. Gen. Tech. Rep. FPLGTR-76. Madison, WI: U.S. Department of Agriculture, Forest Service, Forest Products Laboratory. 13 p.

Skaar C. 1988. Wood-water relations. Springer, Berlin, Germany. doi:10.1007/978-3-642-73683-4

Stamm AJ 1971. Review of nine methods for determining the fiber saturation points of wood and wood products. Wood Science 4:114-128.

Wilkinson S, Ogée J, Domec J-C, Rayment M, Wingate L. 2015. Biophysical modelling of intra-ring variations in tracheid features and wood density of Pinus pinaster trees exposed to seasonal droughts. Tree Physiology 35: 305318. doi:10.1093/treephys/tpv010

Williamson GB, Wiemann MC. 2010. Measuring wood specific gravity...Correctly. American Journal of Botany 97 : 519-524. doi:10.3732/ajb.0900243

Zanne AE, Lopez-Gonzalez G, Coomes DA, Ilic J, Jansen S, Lewis SL, Miller RB, Swenson NG, Wiemann MC, Chave J. 2009. Data from: Towards a worldwide wood economics spectrum. Dryad Digital Repository. doi.org/10.5061/dryad.234

Ziemińska, K., Butler, D. W., Gleason, S. M., Wright, I. J., \& Westoby, M. (2013). Fibre wall and lumen fractions drive wood density variation across 24 Australian angiosperms. AoB Plants, 5, plt046. doi.org/10.1093/aobpla/plt046

Ziemińska K, Westoby M, Wright IJ. 2015. Braod anatomical variation within a narrow wood density range - a study of twig wood across 69 Australian angiosperms. PLoS ONE 10(4): e0124892. doi:10.1371/journal.pone.0124892 